\title{
Adipose-derived adult stem cells and new technique for intracavernosal injection for erectile dysfunction: novel approach to treat diabetes mellitus. Erectus Shot Technique
}

\author{
Carlos Mercado, MD* \\ Medical Director StemCellsMD, 1307 S. International Pkway, Suite 2091, Lake Mary, FL 32746, USA
}

\begin{abstract}
Erectile Dysfunction (ED) affects 10 percent of the population worldwide. In 1995 it was estimated that 152 million men were affected by ED. It is estimated that by 2025352 million of population worldwide will be affected. Currently there is not available treatment that can restore or regenerate the tissues in the corpus cavernosum or arterial system that will cure ED a 20 percent failure rate with present therapies and high rate of drop out in patients with ED due to radical prostatectomy and post radiation. Testosterone eplacement is the only independent risk factor that might help endothelial dysfunction and consequently ED. Adipose tissue is abundant and easy to collect from a miniliposuction. The procedure consists in collecting a lipoaspirate of $60 \mathrm{ml}$. No general Anesthesia is required. It is an outpatient procedure. Adipose tissue is processed using a non animal collagenase enzyme. Stromal vascular fraction (SVF) is isolated. Blood is obtained through a venipuncture. Platelet rich-plasma (PRP) is obtained. The SVF is suspended in PRP. The mixture is injected into the corpus cavernosum using our designed protocol for injection.

Four types of patients: DM, ED due to prostatectomy and radiation, Peyronie's disease, and ED organic cause/aging/vascular. Patients filled out the intensity score questionnaire before and after procedure. Both reported better erections in the morning, firmer, and better response to PDI5 inhibitors for which they were not responders prior to the treatment. This might be due to stem cells induced regeneration of the cavernous nerve and endothelial cells enhancing the nitric oxide production hence improved response to PDI-5 inhibitors.
\end{abstract}

\begin{abstract}
Abbreviations: ED: erectile dysfunction; SC: stem cells; ADSC: adipose-derived stem cell; BMSC: bone marrow stem Cell; SVF: stromal vascular fraction; CC: corpus cavernosum; IC: intracavernous: refers IC injections; SMCs: smooth muscle cells; CSMCs: corpus smooth muscle cells; CN: cavernous nerve; NO: nitric oxide; NOS: nitric oxide synthase; eNOS: endothelial nitric oxide: refers to NO coming from endothelial cells; nNOS: neuronal nitric oxide: refers to NO coming from nerve endings like CN; TA: tunica albuginea; DM: diabetes mellitus; PD: peyronie's disease; CNI: cavernous nerve injury; MPG: major pelvic ganglion; RP: radical prostatectomy; PDE5 (I): phosphodiesterase type 5 (inhibitors); PVN: paraventricular nucleus; GTP: guanosine 5'-triphosphate; cGMP: cyclic guanosine monophosphate; ATP: adenosine triphosphate; C AMP: adenosine monophosphate
\end{abstract}

\section{Introduction}

It appears that ED is becoming an epidemic [1-4]. Unfortunately the present standard care of treatment doesn't offer a therapy to reestablish function of the penile organ. The penile structure is a vascular organ and it is the area of the vascular system that contains the most endothelial cells when compared to other vascular tissues. ED has to be seeing as a systemic disease that in many occasions merit a cardiac evaluation to rule out plaque in the coronary arterial system [5-7]. ED is defined as failure to initiate, failure to fill, failure to store necessary blood volume within the lacunar network [8]

The reason for the high prevalence of ED might be related to humans being now developing the devastating consequences of a poor life style such as smoking, hyperlipidemia, obesity, hypertension, sleep apnea among some of the risk factors [8-10]. The worldwide prevalence of ED was estimated to be 152 million in 1995 and predicted to be 322 million by 2025 . Almost the same size as the population in the United States

The other issue to address is the high failure rate of PDE5 (I) in patients such as DM and after RP and or after radiation to the pelvic area [10]. It appears that main reason for the high failure rate in these subset of patients of patients is due to minimal or lack NO production due to the damage to the $\mathrm{CN}$ creating apoptosis and eventually fibrotic tissue of the CC [10]. The other condition to review is PD (Peyronie's Disease) that causes penile deformity but also is associated with ED. The present urologic surgery for this condition entitles plaque removal from the TA (Tunica Albuginea) which eventually causes more scar tissue and then later on more deformity and ED problems. Currently, we are left with no real option treatments that can reestablish function and then improve the erection process in humans.

The main objectives of this review is to present our outpatient

Correspondence to: Carlos Mercado, MD, Medical Director StemCellsMD, 1307 S. International Pkway, Suite 2091, Lake Mary, FL 32746, USA, Tel: 407-7710404; E-mail: carlosmercadomd@gmail.com

Key words: erectile dysfunction, adipose-derived adult stem cells, corpus cavernosoum, nitric oxide, stromal vascular fraction (svf), platelet-rich plasma (prp), erectus shot technique

Received: February 15, 2016; Accepted: March 08, 2016; Published: March 11, 2016 
protocol of IC injection technique using autologous adipose derived mesenchymal stem cells for ED and review the proposed mechanism of action and to propose the use the IC route as a way of systemic delivery without the need to go directly into the affected organ. The IC injection of a suspension of SVF in PRP appears promising in ED patients due to DM, prostatectomy and radiation for which at present there is not a cure furthermore they have a high rate of Failure to PDI5 inhibitors. The procedure is done as outpatient and requires no general anesthesia. The potential to treat diabetes as early as diagnosed might be a possibility since lower fasting glucose levels and improvement in HbA1C were noticed.

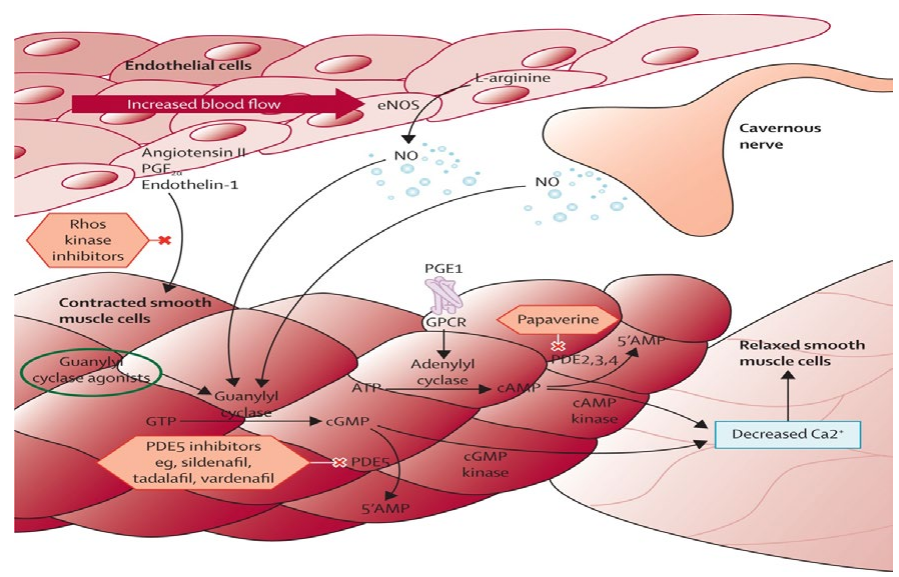

Figure 1. Erection Process. Interaction between Cavernous Nerve, Endothelial cells and Smooth muscle cells. NO (Nitric Oxide) is released by the CN and the Endothelial Cells. NO enters the smooth muscle cells. NO activates the enzyme Guanylyl Cyclase converting GTP to c GMP. PDE5 enzyme converts the cGMP to 5' AMP. The PDE5 inhibitors block the PDE5 enzyme maintaining sufficient levels of cGMP. This leads to decreased calcium causing relaxation of smooth muscle cells. In the relaxed state blood enters into the $\mathrm{CC}$ causing and maintaining an erection. The other enzyme is the Adenylyl cyclase that is nondependence of NO. ATP is converted to c AMP by an Adenylyl Cyclase. cAMP is converted by a cAMP Kinase. The end result is decreased Calcium then allowing blood to enter into $\mathrm{CC}$, causing and maintaining an erection that is not NO dependant.

\section{Erection process}

The erection is a very complex process that requires the integrity of several organ systems in the body as explained below [10,11]. One is the integrity of the corpus cavernosum (CC) (Figure 1). The main components of the CC are: The endothelial cells, smooth muscles and the connection with the $\mathrm{CN}$ (cavernous nerves). The main ingredient appears to be NO (nitric oxide). The erection process requires equilibrium between sympathetic and parasympathetic system (Figure 2). An overdrive of the sympathetic system will make it difficult to have an erection.

Neurotransmitters in the brain are very important such as oxytocin, dopamine among others. Blood entering into the sinusoids (small venules in the CC) will cause the erection process mediated by neurotransmitters in the brain and predominance of parasympathetic system. The neurotransmitters in the brain elicit a positive effect on the PVN (paraventricular nucleus) such as oxytocin, dopamine, glutamic acid, and VGF peptides causing release on NO (nitric oxide) causing calcium influx then increasing NOs (nitric oxide synthetase) then increasing conversion of L- arginine to NO ( nitric oxide). Oxytocin has a positive effect on extra-hypothalamic areas such as hippocampus, amigdala, spinal cord, ventral caudal tegmental areas (Figure 3). The end result is release of NO that is needed by androgens to produce an erection (Figure 3). Clinically speaking brain neurotransmitters play an important role in the erection process. For example, patients using opioids or cannabinoids has a negative effect on the production of NO, blocking the effects of NOs then causing minimal amount of NO. This explains why many patients on Pain medications such as opioids had problems with ED (Figure 3 and 4). So it is very important to understand the mechanisms of action in order to have an erection as follow [10-18]

NO (nitric oxide) released from the endothelial cells and CN (cavernous nerve) at the CC (corpus cavernosum) activate guanylyl cyclase enzyme converting GTP to cGMP $[18,19]$. When cGMP are sufficiently high, activation of c GMP dependent kinase occurs, leading

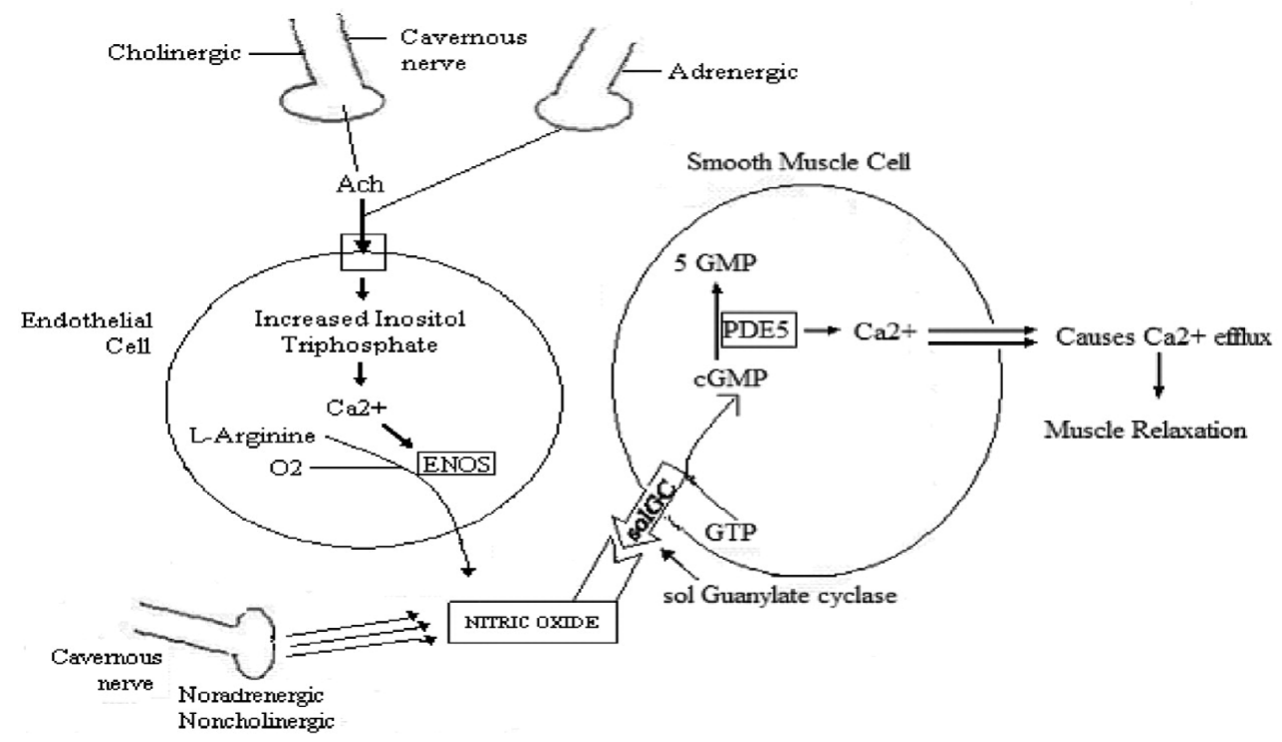

Figure 2. Erection Process in relationship with synergy between Adrenergic and Cholinergic System, Endothelial cells and Smooth Muscle Cells and Cavernous Nerve. The CN by the mediation of the Noradreneergic, Noncholinergic produces NO and the Cholinergic, Adrenergic produces Acethylcholine(Ach). Ach enters the endothelial cell, increasing Inositol Triphosphate and leads to Calcium to convert L- Arginine by ENOS (Endothelial Nitrous Oxide Synthase) leading to NO production. NO activates the conversion of GTP to cGMP . PDE5 Enzyme converts cGMP to 5 GMP. Calcium efffux causes muscle relaxation then allowing blood to enter the CC, then an erection. 
Mercado C (2016) Adipose-derived adult stem cells and new technique for intracavernosal injection for erectile dysfunction: novel approach to treat diabetes mellitus. Erectus Shot Technique

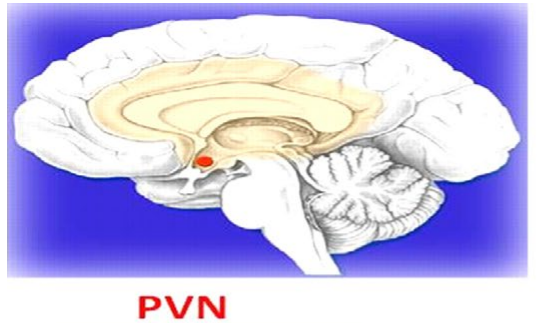

Extra-hypothalamic areas

Ventral caudal tegmental area
Hippocampus
Amygdal
Ventral subiculum
Spinal cord

Spinal cord

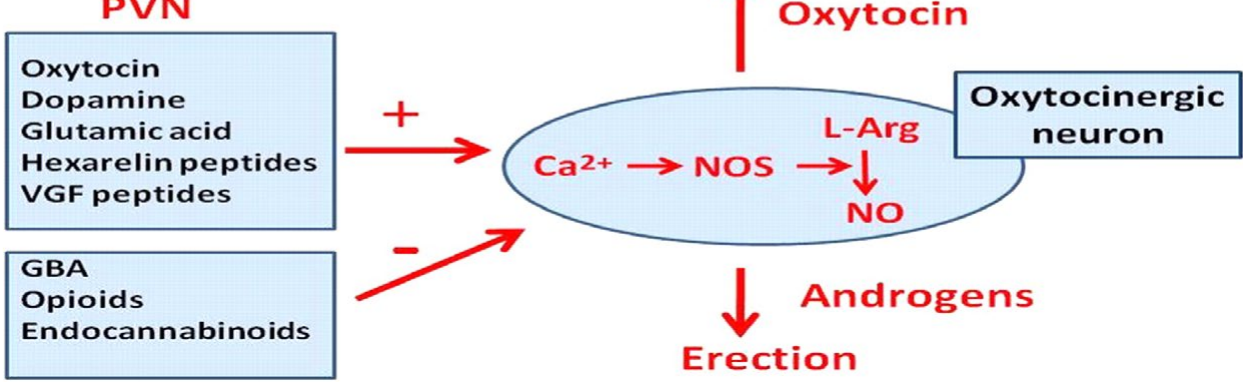

Figure 3. Erection process in relationship with Brain Neurotransmitters. Paraventricular Nucleus (PVN) has positive or negative Mediators in relationship with the production of NO. Oxytocin, Dopamine, Glutamic Acid, VGF has a positive effect. Contrary GBA, opioids, Endocannabinoids has a negative effect. Oxytocin has a positive effect in the Extra-hypothalamic areas such as Hippocampus, spinal cord. NO has a positive effect on androgens that mediate an erection.

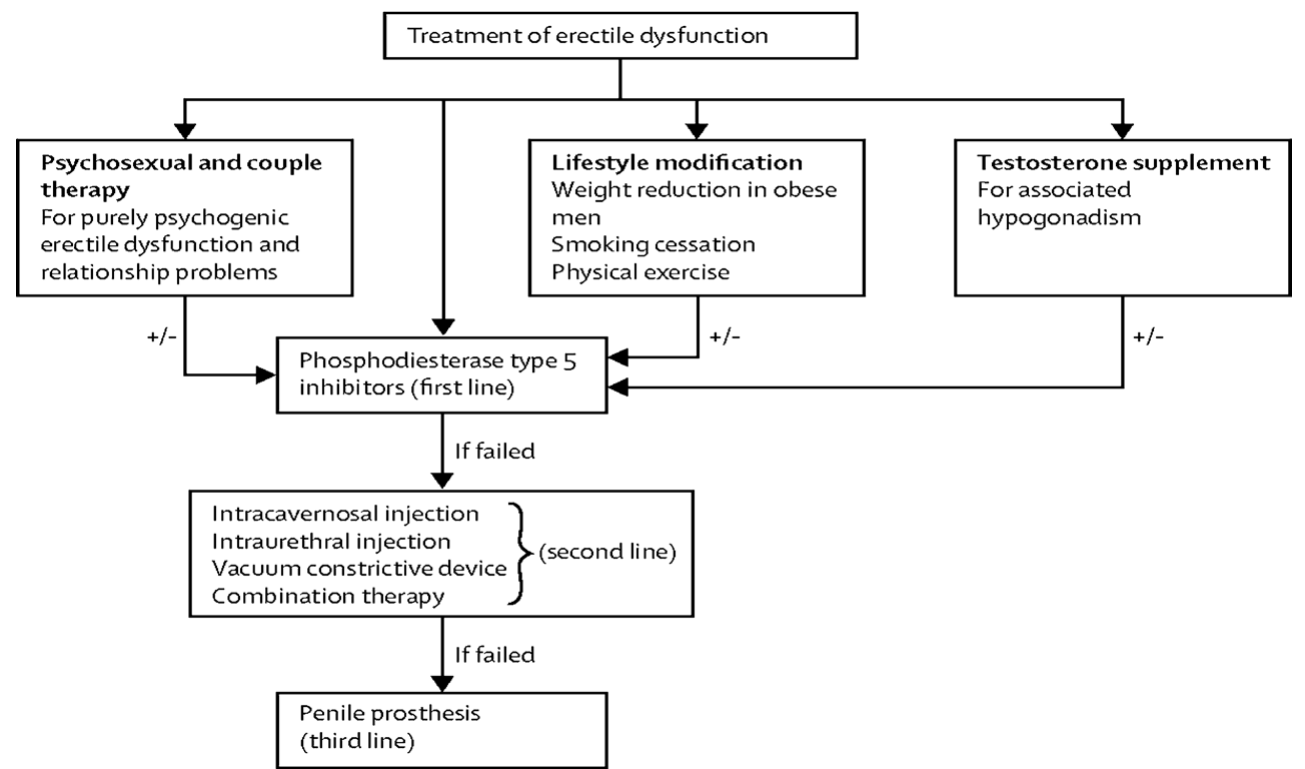

Figure 4. Treatment of erectile dysfunction. First line treatment includes Psychosexual and couple therapy, life style modification, testosterone supplementation for associated hypogonadism all in combination with Phosphodiesterase Type 5 inhibitors. If the above fails then use the second line options such as intracavernosal injection, intraurethral injection, vacuum constrictive device or combination therapy. If the above fails then the third line is a penile prosthesis.

to phosphorylation of several downstream target (ion channels), causing CSMCS to relax, and causing an erection (Figure 1).

PDE5 enzyme [19-25] converts cGMP into 5’ AMP then lowering cGMP levels that are needed for the erection process. Medications such as sildefanil block the PDE5 enzyme then increasing and maintaining levels of cGMP necessary for the erection process. This is a key point that will be discussed later in relationship to high failure rate of PDE5 (I) in the setting of DM or after radical prostatectomy. In order for the PDE5 (I) to work, NO is needed, otherwise they might be ineffective [25].

When sexual stimulation stops, c GMP production is also halted. Then cGMP is hydrolyzed by PDE5 enzyme. Then cGMP is deactivated and converted to 5' AMP. Lowering the levels of cGMP will cause then the smooth muscle cells of the CC to contract and the erection process to stop (Figure 1).

On the contrary there is another enzymatic process that is INDEPENDENT from NO $[25,26]$. It relates to the conversion of ATP to cAMP being converted by Adenylyl Cyclase enzyme (Figure 1). It involves another type of PDE enzyme: PDE 2, 3, 4 that converts cAMP to 5'AMP. C AMP by a CAMP kinase decreases calcium then relaxing the smooth muscle cells causing influx of blood and then an erection. For instance medications such as papaverine block the PDE 2, 3, 4 increasing levels of c AMP that leads to phosphorylation trough a $c$ AMP Kinase and then causing relaxation of smooth muscles and then an erection. Currently many patients, who had DM or after RP that produce minimal or no NO, are on PDE 2, 3, 4 inhibitors, since the medication works without need of NO $[25,26]$. 


\section{Hemodynamics of erection}

In the flaccid state, the arteries, arterioles and sinusoids are CONTRACTED. The intersinusoidal and subtunical venous plexuses are wide open, with free flow through the emissary veins. The $\mathrm{pO}_{2}$ is venous $(35 \mathrm{~mm} \mathrm{Hg})$. In the erect state, the muscles of the sinusoidal wall and the arterioles relax, allowing maximal flow to the compliant sinusoidal spaces. Most of the venules are compressed because expanding sinusoids. Larger venules of sub tunical plexus are sandwiched because the distended sinusoids and the tunica Albuginea that effectively reduces the venous capacity to a minimum. The $\mathrm{pO}_{2}$ here is arterial $(>90 \mathrm{~mm} \mathrm{Hg})$ and ICP $>100 \mathrm{mmHg}[25,26]$.

\section{Causes of ED}

The risk factors for ED are similar to the one for cardiovascular disease. As mentioned before the PENIS is a vascular organ and it

Table 1. Number of published stem cells for erectile dysfunction studies.

\begin{tabular}{|l|c|c|c|}
\hline \multicolumn{3}{|c|}{$\begin{array}{l}\text { 2004-2011 } \\
\text { Number of Studies }\end{array}$} \\
\hline Total & $\mathbf{1 5}$ & $\mathbf{2 0}$ & $\mathbf{3 5}$ \\
\hline Disease Model: & & & \\
\hline \multicolumn{1}{|c|}{ Aging } & 2 & 1 & 3 \\
\hline CN injury & 7 & 12 & 19 \\
\hline Hyperlipidemia & 1 & 0 & 1 \\
\hline T1DM & 2 & 6 & 8 \\
\hline T2DM & 2 & 0 & 2 \\
\hline TA injury & 0 & 2 & 2 \\
\hline ADSC & & & 18 \\
\hline BMMNC & 5 & 13 & 1 \\
\hline BMSC & 1 & 0 & 9 \\
\hline EPC & 4 & 5 & 1 \\
\hline ESC & 1 & 0 & 1 \\
\hline SkMSC & 1 & 0 & 3 \\
\hline Testis SC & 2 & 1 & 1 \\
\hline UCBSC & 0 & 1 & 1 \\
\hline & 1 & 0 & \\
\hline
\end{tabular}

Table 2. Published studies of stem cell therapy for cavernous nerve injury erectile dysfunction.

\begin{tabular}{|c|c|c|c|}
\hline $\begin{array}{c}\text { Publication } \\
\text { year }\end{array}$ & First author & CN injury type & Stem cell type \\
\hline 2004 & Bochinski & Crush & Allogenic ESC \\
\hline 2006 & Kim & Transection & Allogenic SkMSC \\
\hline 2009 & Fall & 5-mm resection & Allogenic BMMNC \\
\hline 2010 & Albersen & Crush & Autologous ADSC \\
\hline 2010 & Kendirci & Crush & Allogenic BMSC \\
\hline 2011 & Lin & 5-mm resection & AutologousADSC \\
\hline 2011 & Woo & Transection & Allogenic SkMSC \\
\hline 2012 & Fandel & Crush & Autologous ADSC \\
\hline 2012 & Kim & Crush & Allogenic BMSC \\
\hline 2012 & Kovanecz & 5-mm resection & Mouse SkMSC \\
\hline 2012 & Piao & Crush & Human ADSC \\
\hline 2012 & Qiu & Radiation & Allogenic ADSC \\
\hline 2012 & Qiu & Crush & Autologous ADSC \\
\hline 2013 & Jeong & Crush & Human ADSC \\
\hline 2013 & Kim & Crush & Human ADSC \\
\hline 2013 & You & Not described & Human BMSC \\
\hline 2013 & You & Stretch & Human ADSC \\
\hline 2013 & Choi & Crush & Human testis SC \\
\hline 2013 & Ying & Crush & Autologous ADSC \\
\hline
\end{tabular}

\begin{tabular}{|c|c|c|}
\hline Modification/supplementation* & Transplantation route & References \\
\hline BDNF transduction & IC or intra-MPG & {$[98]$} \\
\hline None & IC & {$[99]$} \\
\hline None & IC & {$[100]$} \\
\hline None & IC & {$[101]$} \\
\hline P75LNGFR selection & IC & {$[102]$} \\
\hline None & Nerve graft & {$[103]$} \\
\hline None & IC & {$[104]$} \\
\hline None & IC & {$[105]$} \\
\hline BDNF transduction & Intra-MPG & {$[106]$} \\
\hline Oral Sildenafil & IC & {$[107]$} \\
\hline BDNF PLGA & CN scaffold & {$[108]$} \\
\hline None & IV & {$[109]$} \\
\hline None & lC & {$[110]$} \\
\hline BDNF PLGA & CN scaffold & {$[111]$} \\
\hline NGF hydrogel & CN scaffold & {$[112]$} \\
\hline None & IC + Periprostatic & {$[113]$} \\
\hline None & lC + Periprostatic & {$[114]$} \\
\hline None & Periprostatic & {$[115]$} \\
\hline None & lC & {$[116]$} \\
\hline
\end{tabular}

is the richest area of endothelial cells. Hypertension, dyslipidemia, diabetes causes the following effects as atherosclerosis and impaired endothelium-dependent relaxations. Atherosclerosis causes arterial stenosis and impaired endothelium-dependent relaxations causes impaired vasodilation. Then both of them cause ARTERIAL Insufficiency that leads to Reduced Penile inflow.

On the other hand atherosclerosis causes damage to the trabeculae by causing smooth muscle atrophy and fibrosis then leading to venoocclusive dysfunction. The final result is EXCESSIVE penile outflow. By the same token, impaired endothelium-dependent relaxations causes veno-occlusive dysfunction due to impaired relaxation of the trabeculae causing excessive penile outflow. So the final result of this 2 conditions leads to reduced penile inflow and excessive penile outflow so no blood is constantly present causing ED.

Another risk factor for ED that is important is sleep apnea or lung disease that is overlooked many times. Chronic hypoxia appears to be an independent risk factor associated with ED. Hypoxia affects the tone of the blood vessels and induces production of vascular growth factors, inhibiting endothelial-mediated relaxation and causing vasoconstriction. Oxygen may also regulate NO synthesis in the corpus cavernosum (CC). Perhaps hyperbaric chamber treatment might be a proposal to add to the stemcells injection protocol (more data and studies will be needed). The aging process is another risk factor and it is caused by the oxidative stress then leading to ED.

Vascular endothelial dysfunction is the most likely pathophysiology linking ED and coronary artery disease which all share almost the same risk factors such as Hypertension, hyperlipidemia, smoking, obesity, metabolic syndrome. patients with ED have high rates of macrovascular atherosclerosis. Low Testosterone $[26,27]$ is associated with ED as well as with cardiovascular morbidity and mortality. Testosterone regulates the expression of NO synthase and PDE5 and maintains the integrity of the vascular smooth muscle and endothelium. Medications [27] such as Statin used to treat hyperlipidemia has being implicated to ED. B-Blockers potentiating the Alpha 1- adrenergic system can cause ED. SSRI, Risperidone, Olanzapine have the highest likelihood if causing sexual dysfunction. 
Mercado C (2016) Adipose-derived adult stem cells and new technique for intracavernosal injection for erectile dysfunction: novel approach to treat diabetes mellitus. Erectus Shot Technique

\section{Present treatment options for ED}

There are 4 treatment options presently that are used routinely (Table 4). However in many occasions patients just receive PDI5 Inhibitors as option one [27-31]. It is very important to address the cardiovascular risk factors and to be treated accordingly. First line of treatment includes the following (Table 4): Psychosexual and couple therapy; this is for purely psychogenic ED and relationship problems, lifestyle modification; weight reduction in obese men, smoking cessation, physical Exercise, testosterone supplementation for hypogonadism. Second line treatment if the above fails or it can be added it on at the same time are the PDI5 Inhibitors. Third Line if PDI5 Inhibitors failed is (Table 4), intracavernosal injection, intraurethral injection, vacuum constrictive device, and combination therapy. Fourth line if all above failed is a penile prosthesis which has a satisfaction rate of $98 \%$ (Table 4 ). All of the above treatment options offer no restration to the penile tissue and then consequently no cure available for ED. Important to mention that a cardiac evaluation might be necessary since ED is considered a presenting symptom of coronary artery disease.

In a study of 327 patients by A. A. Carvalheira, N. M. Pereira, J. Maroco et al. [31], showed the following:only 148 (45.3\%) of patients were taking the PDE5 inhibitors. $160(48.9 \%)$ had discontinued the PDE5 inhibitors 19 (5.8\%) never took the PDE\% inhibitors. The reason to discontinue the PDE5 Inhibitors was $38 \%$ said the medication was not effective. $15.7 \%$ were concerned about heart safety 13.7 were concerned about cost. The highest dropout rate was in DM, 78\% drop out rate, RP, $66 \%$, and $8.7 \%$ discontinue because of lack of spontaneity. All current treatments treat only symptoms but do not address the underlying causes. The current research is focus to find a therapy that can reverse the pathogenesis of ED and potentially restore the ability to

Table 3. Published studies of stem cell therapy for noncavernous nerve injury, nondiabetic ed.

\begin{tabular}{|c|c|c|c|c|c|c|}
\hline $\begin{array}{l}\text { Publication } \\
\text { year }\end{array}$ & First author & Animal model & Stem cell type & Modification/supplementation* & Transplantation & Reference \\
\hline 2007 & Bivalacqua & Aging rat & Allogenic BMSC & eNOS transduction & lC & {$[117]$} \\
\hline 2008 & Nolazco & Aging rat & Mouse SkMSC & None & IC & [118] \\
\hline 2010 & Abdel Aziz & Aging rat & Allogenic BMSC & None & IC & [119] \\
\hline 2010 & Huang & Hyperlipidemia rat & Autologous ADSC & None & IC & {$[120]$} \\
\hline 2012 & $\mathrm{Ma}$ & TA injury rat & Autologous ADSC & None & SIS graft & [121] \\
\hline 2013 & Castiglione & TA injury rat & Human ADSC & None & Intraunical & {$[122]$} \\
\hline
\end{tabular}

Table 4. Published studies of stem cell therapy for diabetic erectile dysfunction.

\begin{tabular}{|c|c|c|c|c|c|c|}
\hline $\begin{array}{l}\text { Publication } \\
\text { year }\end{array}$ & First Author & Patients/animal model & Stem cell type & Modification/supplementation* & Transplantation route & reference \\
\hline 2010 & Bahk & T2DM patients & Allogenic UCBSC & None & $1 \mathrm{C}$ & {$[123]$} \\
\hline 2010 & Garcia & ZDF rat & Autologous ADSC & None & IC & {$[124]$} \\
\hline 2011 & Gou & STZ rat & Allogenic EPC ${ }^{\#}$ & VEGF transfection & IC & {$[125]$} \\
\hline 2011 & Qiu & STZ rat & Allogenic BMSC & None & IC & [126] \\
\hline 2012 & Qiu & STZ rat & Allogenic BMSC & VEGF transfection & IC & [127] \\
\hline 2012 & Sun & STZ rat & Allogenic BMSC & None & IC & {$[128]$} \\
\hline 2012 & Nishimatsu & STZ rat & Allogenic ADSC & None & $1 \mathrm{C}$ & [129] \\
\hline 2012 & Ryu & STZ mouse & Syngeneic SVF & None & IC & {$[130]$} \\
\hline 2013 & $\mathrm{He}$ & STZ rat & Allogenic BMSC & KCNMA1 transduction & lC & {$[131]$} \\
\hline 2013 & Liu & STZ rat & Human ADSC & VEGF transduction & IC & [132] \\
\hline
\end{tabular}

Table 5. Erectile Intensity Score.

\begin{tabular}{|c|c|c|c|c|c|}
\hline & $\begin{array}{l}\text { Almost never or } \\
\text { never }\end{array}$ & $\begin{array}{l}\text { A few times (much } \\
\text { less than half the } \\
\text { time) }\end{array}$ & $\begin{array}{l}\text { Sometimes (about } \\
\text { half the time) }\end{array}$ & $\begin{array}{l}\text { Most times (much } \\
\text { more than half the } \\
\text { time) }\end{array}$ & $\begin{array}{l}\text { Almost always or } \\
\text { always }\end{array}$ \\
\hline How often were you able to get an erection during sexual activity? & 1 & 2 & 3 & 4 & 5 \\
\hline $\begin{array}{l}\text { When you had erections with sexual stimulation, how often were your } \\
\text { erections hard enough for penetration (entering your partner)? }\end{array}$ & 1 & 2 & 3 & 4 & 5 \\
\hline $\begin{array}{l}\text { When you attempted intercourse, how often were you able to } \\
\text { penetrate (enter) your partner? }\end{array}$ & 1 & 2 & 3 & 4 & 5 \\
\hline \multirow{2}{*}{$\begin{array}{l}\text { During sexual intercourse, how often were you able to maintain your } \\
\text { erection after you had penetrated (entered) your partner? }\end{array}$} & 1 & 2 & 3 & 4 & 5 \\
\hline & Extremely difficult & Very difficult & Difficult & Slightly difficult & Not difficult \\
\hline $\begin{array}{c}\text { During sexual intercourse, how difficult was it to maintain your } \\
\text { erection to completion of intercourse? }\end{array}$ & 1 & 2 & 3 & 4 & 5 \\
\hline
\end{tabular}

Note: The following questions should only be completed by individuals who have been sexually active and have attempted sexual Intercourse in the past 3 months. For sexually inactive individuals, the questionnaire may be answered for the last period of time ( 3 months or longer) during which the individual was sexually active. All questions are preceded by the phrase over the past 4 weeks.

Note: Score: Severe: 1-7. Moderate 8-11. Mild 17-21. No ED: 22-25 
have and or maintain a natural penile erection. One of those options is stem cells that have the potential to regenerate and restore tissue.

\section{How do stem cells travel after IC injection?}

It appears after IC injection the mesenchymal stem cells remain in the CC for at least 4 weeks. In several studies (preclinical data) showed between 1 hour to up to 4 weeks [32-52]. In a study by genomics/ stem cells in urology" use of nanoparticles to monitor human mesenchymal stem cells transplanted into penile cavernosum of rats with erectile dysfunction" [32]. This study was performed to examine the treatment of erectile dysfunction by use of superparamagnetic iron oxide nanoparticles-labeled human mesenchymal stem cells (SPIONMSCs) transplanted into the cavernous nerve injured cavernosa rats as monitored by molecular magnetic resonance imaging (MRI)

Transplanted MSPION-MSC existed for up to 4 weeks in the cavernous nerve injured cavernosa rats. Erectile dysfunction recovered as demonstrated by increased ICP (intracavernosal pressure) and Mean arterial pressure and could be monitored by MRI. In previous preclinical data there were problems with cell tracking due to lack of specific markers. This recent Korean study using nanotechnology and MRI proved that MSC's remain in to the CC for 4 weeks. Mesenchymal stem cells can be differentiated into osteogenic, chondrogenic, or adipogenic components [32]. Stem cells have the capacity to differentiate into endothelial cells leading to new blood vessel formation. Also they differentiate into smooth muscle cells then leading to regeneration of the CC. However since they travel very fast from the CC from 1 hour to up to 4 weeks the proposed mechanism of action seems to be a paracrine effect [32-52]. The stromal vascular fraction (SVF) is obtained from a lipoaspirate (60 $\mathrm{ml}$ of adipose tissue usually is required). The description of our protocol will be depicted below. SVF is composed of mesenchymal stem cells, endothelial cells, fibroblasts, growth factors, pericytes, and smooth muscle cells. The SVF pellet contains most of the time 250.000 cells, but only $2 \%$ can adhere in the plastic dish, so only $2 \%$ become ADSC (adult stem cells).

\section{$\mathrm{RP} /$ Pelvic radiation}

Prostate cancer is the most common malignancy in men: Approximately $80 \%$ prostate cancer is mainly localized [53-67]. In the USA in 2010: 217.730 new cases were diagnosed and reported deaths of 32.050. One of the major and devastating complications of RP is ED approximately $60.8 \%$ and ED post radiation therapy is 93.90 percent rate of discontinuation of PDE5 inhibitors in patients with ED after $\mathrm{RP}$ (radical prostatectomy) is close to $66 \%$ and they are only successful in $43 \%$.

Cavernous nerve runs alongside the prostate. RP even with the introduction of nerve-sparing RP 30 years ago, inadvertent injury to the CN's or just even the CN's intact causes subtle changes that are not seeing or obvious during the RP. There are CN's injury models either by "crushing" or "resection" of the CN's (Table 5B).

In patients after Radical Prostatectomy or Radiation of the prostate, stem cells after IC injection travel to the major pelvic ganglia of CV (cavernous nerve) and then from there start regenerating the fiber nerves that had gone wallerian degeneration and consequently trying to improve the release of $\mathrm{NO}$ (nitric oxide) to try to reestablish the connection between the $\mathrm{CN}$ (corpus nerve) and the corpora cavernosa. Unfortunately after RP (radical prostatectomy) the CN gets injured and consequently no release of NO (nitric oxide) in the CC (corpus cavernosum) leading to no engorgement of small sinusoids located in the CC and then this leads to hypoxia of the CC then smooth muscle cells are replaced by collagen. The preclinical data using CN injury models showed reduced smooth muscle to collagen ratio. This eventually leads to atrophy of smooth muscle cells in the CC (corpus cavernosum). The lack of NO explains the reason why PDE5 inhibitors don't work properly.

\section{Diabetes mellitus}

In 2011 in the USA, 25.8 million (8.3\% of the population) and 10.9 million were 65 year or older affected by DM [68-74]. In 1980 in the world there were 153 million affected by DM. In 2008 in the world were 347 million affected by DM. It is estimated that by the year 2030 it would be 552 million affected by diabetes mellitus.

\section{In patients with diabetes mellitus}

50 to $75 \%$ of patients with diabetes mellitus have ED. Important to mention that ED in patients with DM appears 10 to 15 years earlier [7476]. The success rate of ED in patients with DM taking PDE5 Inhibitors is only 44 percent and diabtetic patients has the highest drop ut rate closing to 78 percent. It is here where the IC Adult stem cell injection might be benefitial and perhaps a novel treatment to treat not only ED but also DM at earlier age or even before their insidous beginning.

\section{Mechanism of action of DM causing ED}

The proposed mechanism of how diabetes mellitus causes ED has to do mainly with apoptosis [76-81]. Preclinical data have shown mitochondrial fragmentation as well as reduced contents of $\mathrm{CN}$ (corpus nerve) cell death nNOS- positive neurons in the MPG (major pelvic ganglia), CEC (cavernous endothelial cells) and CSMC (cavernous smooth muscle cells). One of the main functions of adult stem cells (MSC) is their antiapoptic capacity and ability to regenerate tissue, angiogenesis, antifibrotic and stem cell differentiation.

\section{Peyronie's disease- associated ED}

$\mathrm{PD}$ affects $7.1 \%$ of the general population [82-93]. There is a PLAQUE formation on the TA (tunica albuginea) that might cause pain, penile deformity and shortening of the erect Penis. PD also is accompained by ED. However most PD patients are able to obtain an erection. In a study by Lopez [84]: 76 out of 95 (80\%) had associated ED and $36 \%$ had abnormal arterial blood flow. $59 \%$ of PD in Lopez study had veno-occlusive dysfunction which seems to be the main cause of ED. However the plaque was never examined to evaluate it as a cause of the ED. No study so far provides evidence that PD (TA plaque) is a DIRECT cause of ED. It appears that TA abnormalities can cause ED. IC Stem cells injection improves the penile deformity as well as the associated ED.

\section{Studies}

Interesting enough the first stem cell ED was published in 2004 (Table 1) [25,94-131]. Then up to November of 2013, there have been a total of 34 additional studies (Table 2). 20 studies were published after 2011 (Table 2). So the question is why the acceleration on performing studies on ED that obviously occurred after 2012. There are 35 Preclinical Studies and the US and the French clinical trial; 19 studies for CN injury ED (Table 1 and 2) and 10 diabetic ED studies (Table 1 and 4). Most of the studies Stem cells were obtained from adipose tissue (Table 1). Stem cells were injected IC, IV or Periprostatic. All 35 studies Improve Erectile Function in ED patients and Animal Models (Tables $2-4)$. Studies showed increment of ICP by $70 \%$ compared with non-ED 
models in order to produce erection enough for penetration (Tables 1-4). Studies showed improvement in Smooth muscle, endothelium and Nerve of erectile tissue (Tables 2-4). Few studies documented SC engraftment or differentiation, demonstrating that the benefit of the stem cells seems to be mediated by a paracrine effect perhaps mediated by Fibroblast growth factor, CXCL5 cytokine which is a potent angiogenic and Neutrotrophic factor.

In $\mathrm{DM}$ it showed lowering of glucose and $\mathrm{Hb} \mathrm{A} 1 \mathrm{C}$ : Preclinical data showed 2 phases: Early phase in which the SC promote B-cell function. LATE phase improves insulin resistance. Mediated by increase in GLUT 4 expression and elevation of phosphorylated insulin receptor substrate 1 (IRS-1) and AKT protein kinase B in insulin target tissues.

As mentioned previously the majority of SC exit within 1 day to up to 4 weeks (recent study done by nanotechnology and MRI showed at 4 weeks exiting) and time dependent decline. Preclinical data has difficulty showing SC in the CC even though improvement in erectile function and the SC appear to have preference to travel to bone marrow, supporting the role of being mesenchymal cells. In CN injured rat model the SC travel to MPG (major pelvic ganglia) mediated by upregulated SDF-1.Then they travel to the bone marrow supporting their origin and then they act as a reservoir for sustained regenerative and repair activities. In preclinical data the average amount was 1 million stem cells injected into the CC.

A very important point is that the IC (intracavernous) route is very similar to IV (Intravenous). Cavernous sinusoids is just bundle of venules similar to Intravenous. Blood flow in a flaccid state in the CC is SLOWER compared to systemic circulation, thus allowing superior retention into the CC. As mentioned previously the penile vasculature is the most endothelial-rich area in the body so even small amount of cells would be enough for grafting. Since the rational of how stem cells work seems to be more a paracline effect that engrafting then small amount of stem cells will be enough to be injected and to see improvements. The theory proposed is that from IC route SC can travel to Bone marrow since they are mesenchymal stem cells and had predilection to go to one of their site of origin which is the bone marrow and then from there perhaps modulate the immune system, prevent apoptosis, vasculogenesis, to other organs perhaps the heart, kidneys as example and then to continue the regeneration process. The IC stem cell injection perhaps might be an alternate route that is less technical difficult than to attempt to seed SC into the pancreas or heart as an example. This alternate route needs more study. One way would be to use nanotechnology markers and track them by MRI and see what other actions take in other organs. Perhaps once in the bone marrow they just direct or send signals to other cells and work in that way. Present approaches for stem cell therapy is to deliver the cells on the site of injury as example doing a Cardiac Catheterization and putting them in the vasculature or injecting into the myocardium, which is a high risk procedure compared to IC injection.

Preclinical and clinical data also showed reduced peak velocities in ED models with an average of $22 \mathrm{~cm} / \mathrm{sec}$ in cavernosal arteries (Table 4). After IC SC injection peak velocities increased to more than $70 \mathrm{~cm} /$ sec which seems to be the peak velocity needed to obtain an erection.

Allogenic umbilical mesenchymal stem cells have been injected as well into the CC. No adverse effect. No allergic reactions. In the Korea Study in 2010 by JY Bahk and Lee 15 million Allogenic Umbilical cord blood were injected into the CC. It showed an Antidiabetic effect in the 7 Diabetic patients Type 2 .
There are currently 2 clinical trials. The French Trial Phase I-II looking at the safety of IC bone marrow mononucleated cells in post RP ED patients. The USA trial: looking at the safety and treatment efficacy of IC injections of autologous ADSC in organic erectile dysfunction.

\section{Technique of IC stem cell injection: erectus shot tech- nique and protocol}

There is no description in the literature depicting exactly the IC stem cell injection. Preclinical and clinical data describe it as just IC injection. I will describe the ERECTUS SHOT Technique that if done properly will have minimal risk for complications. The protocol for ED will be described as well.

Since the 2 main mechanism of action of Stem cells work are either by Cell differentiation/engraftment and or Paracrine action. Cell engraftment has being poorly documented sustaining that is more the Paracrine effect of the Stem cells. Based on that principle, SVF is placed in PRP (Platelet-Rich Plasma). PRP is rich in growth factors and it is a simple procedure.

Patients undergo a detailed targeted history looking at risk factors as mentioned previously such as cardiovascular risk factors such as Hypertension, Hyperlipidemia, obesity, Metabolic Syndrome, sleep apnea as among others.

Questionnaires before treatment are used: ED Intensity score (Table 5). The ED intensity score relates to ability to have an erection and able to do partner penetration and ability to maintain an erection. A physical exam is performed looking for carotid bruits, heart murmurs, gallops, abdominal bruits, pulses and vascular and perfusion. Also a Genitalia exam, penis evaluation such as size at flaccid state and deformities, penile plaques, testicular size and testicular nodules. Also Rectal and Prostate Examination.

\section{Penile examination}

\section{Length}

Normal length is variable from race to race, but there is an accepted average. Measurement are taken in the non-erect state by pulling on the glans forwards to stretch the penis and dipping the ruler into the pubic fat that surrounds the penis down to the bone, so that the measurement is taken from the bone to the glans, and not from the skin to the glans. This measures the actual length of the penis and not the apparent length. The stretched non-erect length should at least be $7 \mathrm{~cm}$. In the erect state, length measured in the same way should be at least 11 $\mathrm{cm}$. The length of the vagina is $10 \mathrm{~cm}$ on average, which makes $11 \mathrm{~cm}$ a normal length for the penis.

\section{Width and diameter}

There is no consensus about the normal diameter, but if measured with a taper, the perimeter should at least be $10 \mathrm{~cm}$. It has to be noted that the vagina is surrounded by muscles that tighten it around the penis, regardless its diameter.

\section{Straightness}

The penis is mostly straight. However, many men have variable degrees of curvature affecting the penis. This poses cosmetic problems. This may also make intercourse difficult or painful to the female if curvature is more than 30 degrees, especially if it is downwards or to either side. By curvature we mean that the penis is straight at its base but has a bending point distally. A straight penis pointing upwards, 
downwards or to a side without a bent is not considered curved.

\section{Angle}

The penis usually makes an angle of around 90 degrees relative to the surface of the abdomen. This may vary. The angle may be acute with the penis pointing upwards, or obtuse with the penis pointing downwards. This is acceptable as long as it does not make intercourse difficult or disturb the individual or his partner psychologically. A rigid penis pointing downwards is an erect penis. Erection does not necessarily mean that the penis should point forwards or upwards.

\section{Urethral meatus}

This is the urine outlet at the tip of the penis in the glans. Hypospadias is a disorder where the urethral meatus is not at the tip but is somewhere along the lower surface of the penis. This may require surgical correction.

A protocol has being designed exclusively as part of the erectus shot procedure and includes: $\mathrm{CBC}, \mathrm{CMP}, \mathrm{TSH}, \mathrm{HBA1C}$, insulin, lipids, testosterone total and free, estradiol, LH, prolactin, PSA, U/A. Medical clearance with EKG is performed as well. Informed consent for IC injection and liposuction and informed consent for risks/benefits/ possible side effects are discussed with the patient. Cardiac status evaluation as required.

\section{Methods}

Patient undergoes a fat harvesting using water assisted liposuction. One of the main reason this technology is used it is because integrity of the fat and even ability to see attached blood vessels to the adipose tissue. Also a fast recovery for the patient when compared to traditional liposuction or manual syringe aspiration. Water-assisted liposuction (WAL) is a liposuction procedure that provides favorable results concerning patient comfort and aesthetic outcome.

WAL adipose tissue is a valid source of adMSC, yielding numbers of cells that lie within the range of cell numbers isolatable from adipose tissue harvested with other techniques. The adMSC isolated from WAL tissue are viable and possess mesenchymal differentiation potential. In this respect WAL tissue may be used for autologous fat grafting and is an appropriate source for adMSC isolation. The stromal vascular fraction of WAL tissue showed high viability and contained an average of $2.6 \times 105 \mathrm{CD} 34$-positive cells per milliliter of tissue. The yield of stromal vascular fraction (SVF) from WAL harvested fat is reasonably high, with an average of $6.1 \times 105$ cells per gram of tissue and a high fraction of CD34 positive cells. The MSCs isolated from WAL harvested fat are adherent to tissue culture plastic and proliferate in culture [132].

Also simple learning curve for the new physician learning liposuction. As well as the ability to infiltrate the Tumescent fluid in a very rapid way and very homogeneous. Also the equipment is able to remove 30 percent of the tumescent fluid infiltrated it so minimizing the risk of lidocaine toxicity that can be lethal. Also it has the ability to place more tumescent fluid as necessary. The system is closed and fat goes to a special sealed container called the lipocollector that keep the adipose tissue sterile.

The areas chosen for liposuction are clean with a warm skin cleanser (chlorhexidine) in a sterile fashion preparation. The physician wears sterile gloves and surgical gowns for body, head and mouth mask. 100 $\mathrm{ml}$ of adipose tissue is usually harvested. Important to mention is that during the fat harvesting procedure no general anesthesia is used.
Minimizing the risk for complications from liposuction. The patient remains alert and awake. No IV sedation is necessary.

Laboratory suite is adnexa to our surgical room suite. Once fat is harvested then is taken to the Lab in a sterile fashion in the closed lipocollector. Laminar Hood has being activated previously. The lipocollector with the Fat is placed into the laminar Hood. Then fat is processed as per our Protocol. An animal origin free (AOF) enzyme is used for the fat digestion process or using our non-enzymatic fat processing that is operator dependent. Our non-enzymatic process focus on washing and centrifugation. The amount and availability and clinical response of the SVF are similar but use no enzyme. Optionally you may use a flow cytometry or cell counter. Once the SVF is obtained, pellet is separated. The pellet is mixture with $12 \mathrm{ml}$ of PRP.

\section{Frectus shot technique}

\section{Anatomy and rationale for technique IC Injection}

It is important to understand the anatomy of the penis in order to do the proper IC injection. Avoiding complications such as urethral perforation, perforation of the dorsal artery, vein rupture causing hematomas, priapism and or nerve damage. There are 3 cylinders in the penis surrounded in 2 thin layers of muscle with fascia and a layer of skin. One of the three cylinders is the CORPUS SPONGIOSUM that covers the urethra. The other 2 cylinders are: Right corpus cavernosum and left corpus cavernosum.

Each CC is composed of erectile tissues in the form of microscopic spherical spaces called sinusoids that accommodate blood and expand when blood flow into them increases. Each sinusoid is surrounded by smooth muscle that controls its diameter. The sinusoids are enclosed in the outer wall of the CC that is firms, expandable layer of fibrous tissue named the Tunica Albuginea.

The neurovascular bundle is a collection of nerves, arteries and a vein that course along the penis on its upper surface, from the glans to the base of the penis. It includes the nerves that convey sensation from the glans: the dorsal nerve of the penis. As described below one of the areas to avoid injection is at 12 o'clock because of the dorsal location of the neurovascular bundle. At the base of the penis (towards the abdomen), the corpora cavernosa are attached to the bony pelvis by adhesions to between their deepest parts (the crura) and bone, and by a ligament that attaches the corpora cavernosa to the middle of the pelvis and to the anterior abdominal wall: the suspensory ligament.

Each corpus cavernosum has a feeding artery that fills it with blood, and a draining vein that lets blood out. The vein starts inside the corpus cavernosum between its wall (tunica albuginea) and the sinusoids, such that if the sinusoids expand, they may compress the vein and prevent blood from exiting the corpus cavernosum. The penis is covered by skin, underneath which is a thin layer of tissue named the Colle's fascia, beneath which is a thin muscle called Dartos Muscle or Buck's fascia.

\section{Description: erectus shot IC injection}

A triple anesthetic cream is placed on the penile area, left for 45 minutes. Patient is also instructed on the use of self- administered of oxygen and nitrous oxide 50-50 concentration. It is a patientcontrolled analgesic for In-Office use and takes effects in seconds, offering immediate relief of pain and anxiety. Important to mention that in this concentration of 50-50 oxygen/nitrous oxide it behaves as an analgesic and not as an anesthetic. Patients undergoing the Erectus shot procedure might anticipate pain which in terms creates anxiety. 
The erectus technique includes proper marking of the penis in the standing position. The IC injection is performed in the supine position with head elevated at 45 degree angle. The penis is marked as follow: In the standing position in which the penis is in a flaccid state the physician then elevates and grabs the penile organ in a 90 degree angle, parallel to the abdomen.

A clock imaginary marking is performed. Use a marker pass 3 lines: one at 12 o'clock, the second one at 3 o'clock and the third one at 9 o'clock. Use a marker to identify the point of injections which will be at 2 and 10 o'clock. Usually 2 or 4 points of injections are done, depending on the size of the penis or sometimes the amount of PRP available from the patient. The $12 \mathrm{ml}$ suspension of PRP and pellets is divided in $3 \mathrm{ml}$ each in syringes of $3 \mathrm{ml}$. A $28^{3 / 4}$ needle is used for injection.

The needle will penetrate the following structure: skin, then a thin layer called the colle's fascia, then a thin muscle called dartos muscle or buck's fascia then the injector will feel the sensation I called "rupturing a thin membrane". Upon entering the corpus cavernosoum the injector will experience a sensation of "rupturing a thin membrane". Once inside the CC there should be no resistance to the injection process and the mixture of PRP and SVF should flow easily.

At the end of the procedure a compression garment is placed on the area of the liposuction. Patients can have sexual intercourse the same day. As a measure of precaution patients are asked to void before discharging home to make sure there is no gross hematuria. The Erectus technique if performed correctly should no cause any ecchymoses, hematomas.

Proper training is required: The main elements are: Stem cells Fat digestion process, laboratory requirements, stem cell knowledge, blood processing protocols to obtain the PRP (Platelet Rich plasma) liposuction technique with proper patient selection and tumescent anesthesia, erectus IC injection technique. It is imperative that the physician providing this treatment is properly trained.

The erectus shot procedure and protocol has being designed to be done as an outpatient. No general anesthesia is required. Using the tools mentioned the procedure can be performed in an office setting following basic laboratory and liposuction guidelines. The linear curve to learn the procedure depends on many factors. Those factors might include prior liposuction training or some basic surgical skills. For a physician with no experience at all the linear curve goes exponentially and easy to achieve depending on their training. Adipose tissue from water assisted- liposuction.

\section{Conclusions}

Our technique it is a safe procedure obtained from lipoaspirate from liposuction. Our preferred technique is the WAL (water- assisted liposuction) due to higher counts after fat digestion and easy on the patient and excellent integrity of the adipose tissue. Preclinical data and clinical data showed recovery in erectile dysfunction. Proper training and stem cell protocol guidance are important in order to avoid complications. Complications are rare if proper procedure technique is followed. Laboratory guidelines and fat digestion process using either Animal Free origin enzyme or non-enzymatic allows for proper SVF with good viability and excellent counts of stem cells.

The mechanism of action of the IC stem cells appears to be related to a trophic mechanism. The engraftment appears to be poorly documented, even though improvement in ED is achieved. However the stem cells appear to remain the CC for at least 4 weeks. Then they travel to the bone marrow as they are mesenchymal in origin.

The objective of this article is to bring preclinical data that can be applied to the outpatient clinical setting bringing a new protocol The other main point of this review is to propose that perhaps using the IC injection might be an alternate route to deliver Mesenchymal cells to the circulation since it resembles the IV. The proposed idea is that perhaps using the IC injection the stem cells travel to the bone marrow and from there direct and or sent signals to other organs such as the pancreas, obviating the need to place stem cells into the pancreas directly which is a very high risk procedure for complications such as bleeding, pancreatitis, sepsis among others. The same might perhaps apply to other organs such as the heart, which currently studies deliver stem cells into the coronary circulation being flushed rapidly or injected into the myocardium, which again is a very high risk procedure for complications.

All preclinical and clinical data showed the IC stem cells injection to be safe and all showed improvement in IC peak systolic pressure. Also studies showed to be antidiabetic, lowering blood sugar and HbA1C. ED appears at least 10 to 15 years earliest before DM onset, so perhaps injecting those patients at earlier time might ameliorate not only the devastating effects of ED but also Diabetes Mellitus. More studies are needed to see the trafficking of stem cells from the CC to other organs. Perhaps using nanotechnology and MRI to track down the stem cells.

Patients with ED due to RP and or radiation, diabetes have a high failure rate to PDE5 (I) inhibitors and unfortunately this therapy offers no restorative function since they need nitric oxide production from the endothelial cells and cavernous nerve to be effective. Unfortunately DM and RP patients have a very low production of Nitric Oxide. Stem cells have the potential to reestablish function, in the cavernous nerve and endothelial function enhancing the nitric oxide production making the PD5 inhibitors to work better in the setting of DM and RP.

In conclusion, the use of intracavernosal autologous adipose derived stem cells injection appears to be a safe, and effective alternative option for patients suffering with ED related to DM, Post RP, and organic causes. More studies are underway to hopefully make this procedure available to the general population.

\section{Conflicts of interest}

None.

\section{References}

1. (1992) Impotence. NIH Consens Statement 10: 1-33. [Crossref]

2. Inman BA, St.Sauver JL, Jacobsonetal DJ (2009) A population based, longitudinal study of erectile dysfunction and future coronary artery disease. Mayo Clin Proc 84: 109-113. [Crossref]

3. Jackson G, Boon N, Eardley I, Kirby M, Dean J, et al. (2010) Erectile dysfunction and coronary artery disease prediction: evidence-based guidance and consensus. Int $J$ Clin Pract 64: 848-857. [Crossref]

4. Chew KK, Finn J, Stuckey B, Gibson N, Sanfilippo F et al. (2010) Erectile dysfunction as a predictor for subsequent atherosclerotic cardiovascular events: findings from a linked-data study. J Sex Med 7:192-202. [Crossref]

5. Dong JY, Zhang YH, Qin LQ (2011) Erectile dysfunction and risk of cardiovascula disease: meta-analysis of prospective cohort studies. J Am Coll Cardiol 58: 1378-1385. [Crossref]

6. Wagner G1, Fugl-Meyer KS, Fugl-Meyer AR (2000) Impact of erectile dysfunction on quality of life: patient and partner perspectives. Int J Impot Res 12: S144-S146. [Crossref]

7. Ayta IA, McKinlay JB, Krane RJ (1999) The likely worldwide increase in erectile dysfunction between 1995 and 2025 and some possible policy consequences. BJU Int 
Mercado C (2016) Adipose-derived adult stem cells and new technique for intracavernosal injection for erectile dysfunction: novel approach to treat diabetes mellitus. Erectus Shot Technique

84: 50-56. [Crossref]

8. Melman A, Davies K (2010) Gene therapy for erectile dysfunction: what is the future? Curr Urol Rep 11: 421-426. [Crossref]

9. McCullough AR, Barada JH, Fawzy A, Guay AT, Hatzichristou D (2002) Achieving treatment optimization with sildenafil citrate (Viagra) in patients with erectile dysfunction. Urology 60: 28-38. [Crossref]

10. Kendirci M, Hellstrom WJ (2004) Current concepts in the management of erectile dysfunction in men with prostate cancer. Clin Prostate Cancer 3: 87-92. [Crossref]

11. Phé V, Rouprêt M. (2012) Erectile dysfunction and diabetes: a review of the current evidence-based medicine and a synthesis of the main available therapies. Diabetes Metab 38: 1-13. [Crossref]

12. Lue TF (2000) Erectile dysfunction. N Engl J Med 342: 1802-1813. [Crossref]

13. Meldrum DR, Burnett AL, Dorey G, Esposito K, Ignarro LJ (2014) Erectile hydraulics: maximizing inflow while minimizing outflow. International Society for Sexual Medicine. J Sex Med 11: 1208-20. [Crossref]

14. Lin G, Qiu X, Fandel TM, Albersen M, Wang Z, et al. (2011) Improved penile histology by phalloidinstain: circular and longitudinal cavernous smooth muscles, dualendothelium arteries, and erectile dysfunction associated change. Urology 78: 970. e1-970.e8. [Crossref]

15. Alwaal A, Zaid UB, Lin CS, Lue TF (2015) Stem cell treatment of erectile dysfunction. Adv Drug Deliv Rev 82-83: 137-44. [Crossref]

16. Dorsey P, Keel C, Klavens M, Hellstrom WJ (2010) Phosphodiesterase type 5 (PDE5) inhibitors for the treatment of erectile dysfunction. Expert Opin Pharmacother 11: 1109-1122. [Crossref]

17. Garaffa G, Trost LW, Serefoglu EC, Ralph D, Hellstrom WJ (2013) Understanding the course of Peyronie's disease. Int J Clin Pract 67: 781-788. [Crossref]

18. Walsh TJ, Hotaling JM, Lue TF (2013) How curved is too curved? The severity of penile deformity may predict sexual disability among men with Peyronie's disease. Int J Impotence Res 25: 109-112.

19. Lopez JA, Jarow JP (1993) Penile vascular evaluation of men with Peyronie's disease. J Urol 149: 53-55. [Crossref]

20. Culha M, Alici MB, Acar O, Mutlu N, Gokalp A (1998) The relationship between diabetes mellitus, impotence and venoocclusive dysfunction in Peyronie's disease patients. Urologia Internationalis 60: 101-104,1998.

21. Stecker JF Jr, Devine CJ Jr (1984) Evaluation of erectile dysfunction in patients with Peyronie's disease. J Urol 132: 680-681. [Crossref]

22. Bivalacqua TJ1, Diner EK, Novak TE, Vohra Y, Sikka SC, et al. (2000) A rat mode of Peyronie's disease associated with a decrease in erectile activity and an increase in inducible nitric oxide synthase protein expression. J Urol 163: 1992-1998. [Crossref]

23. Martinez D, Ercole CE, Hakky TS, Kramer A, Carrion R (2012) Peyronie's Disease: Still a Surgical Disease. Adv Urol 2012: 206284. [Crossref]

24. Kadioglu A, Sanli O, Akman T, Ersay A, Guven S, et al. (2007) Graft materials in Peyronie's disease surgery: a comprehensive review. J Sex Med 4: 581-595. [Crossref]

25. L Ma L, Yang Y, Sikka SC, Kadowitz PJ, Ignarro LJ, et al. (2012) Adipose tissuederived stem cell-seeded small intestinal submucosa for tunica albuginea grafting and reconstruction. Proc Natl Acad Sci U S A 109: 2090-2095. [Crossref]

26. Castiglione F, Hedlund P, Van der Aa F, Bivalacqua TJ, Rigatti P, et al. (2013) Intratunical injection of human adipose tissue-derived stem cells prevents fibrosis and is associated with improved erectile function in a rat model of Peyronie'sdisease. Eur Urol 63: 551-560. [Crossref]

27. Jemal A, Siegel R, Xu J, Ward E (2010) Cancser statistics, 2010. CA Cancer J Clin 60: 277-300. [Crossref]

28. Brandeis J, Pashos CL, Henning JM, Litwin MS (2000) A nationwide charge comparison of the principal treatments for early stage prostate carcinoma. Cancer 89 : 1792-1799. [Crossref]

29. Dean RC, Lue TF (2005) Neuroregenerative strategies after radical prostatectomy. Rev Urol 7 Suppl 2: S26-32. [Crossref]

30. Kendirci M, Bejma J, Hellstrom WJ (2006) Update on erectile dysfunction in prostate cancer patients. Curr Opin Urol 16: 186-195. [Crossref]

31. Resnick MJ, Koyama T, Fan KH, Albertsen PC, Goodman M, et al. (2013) Long-term functional outcomes after treatment for localized prostate cancer. N Engl J Med 368 :
436-445. [Crossref]

32. V Ficarra V, Novara G, Ahlering TE, Costello A, Eastham JA, et al. (2012) Systematic review and meta-analysis of studies reporting potency rates after robot assisted radical prostatectomy. Eur Urol 62: 418-430.

33. Pardo Y, Guedea F, Aguiló F, Fernández P, Macías V, et al. (2010) Quality-of-life impact of primary treatments for localized prostate cancer in patients without hormonal treatment. J Clin Oncol 28:4687-4696. [Crossref]

34. Fode M, Ohl DA, Ralph D, Sønksen J (2013) Penile rehabilitation after radical prostatectomy: what the evidence really says. BJU Int 112: 998-1008. [Crossref]

35. Albersen M, Kendirci M, Van der Aa F, Hellstrom WJ, Lue TF, et al. (2012) Multipotent stromal cell therapy for cavernous nerve injury-induced erectile dysfunction. $J \mathrm{Sex}$ Med 9: 385-403. [Crossref]

36. Ferrini MG, Davila HH, Kovanecz I, Sanchez SP, Gonzalez-Cadavid NF, et al. (2006) Vardenafil prevents fibrosis and loss of corporal smooth muscle that occurs after bilateral cavernosal nerve resection in the rat. Urology 68: 429-435. [Crossref]

37. Klein LT, Miller MI, Buttyan R, Raffo AJ, Burchard M, et al. (1997) Apoptosis in the rat penis after penile denervation. J Urol 158: 626-630. [Crossref]

38. Lysiak JJ, Yang SK, Klausner AP, Son H, Tuttle JB, et al. (2008) Tadalafil increase Akt and extracellular signal regulated kinase $1 / 2$ activation, and prevents apoptotic cell death in the penis following denervation. J Urol 179: 779-785. [Crossref]

39. Leungwattanakij S1, Bivalacqua TJ, Usta MF, Yang DY, Hyun JS, et al. (2003) Cavernous neurotomy causes hypoxia and fibrosis in rat corpus cavernosum. $J$ Androl 24: 239-245. [Crossref]

40. Hu WL, Hu LQ, Song J, Li SW, Zheng XM, et al. (2004) Fibrosis of corpus cavernosum in animals following cavernous nerve ablation. Asian J Androl 6: 111-116. [Crossref]

41. Iacono F, Giannella R, Somma P, Manno G, Fusco F, et al. (2005) Histological alterations in cavernous tissue after radical prostatectomy. J Urol 173: 1673-1676. [Crossref]

42. Qiu X, Fandel TM, Lin G, Huang YC, Dai YT, et al. (2011) Cavernous smooth muscle hyperplasia in a rat model of hyperlipidaemia-associated erectile dysfunction. BJU Int 108: 1866-1872. [Crossref]

43. Awad A, Alsaid B, Bessede T, Droupy S, Benoît G (2011) Evolution in the concept of erection anatomy. Surg Radiol Anat 33: 301-312. [Crossref]

44. Dail WG, Trujillo D, de la Rosa D, Walton G (1989) Autonomic innervation of reproductive organs: analysis of the neurons whose axons project in the main penile nerve in the pelvic plexus of the rat. Anat Rec 224: 94-101. [Crossref]

45. Lin CS (2004) Lue TF Cyclic nucleotide signaling in vascular and cavernous smooth muscle: aging-related changes, in Advances in Cell Aging and Gerontology, E.Bittar, Ed.16: 57-106.

46. Lin CS, Lin G, Lue TF (2005) Cyclic nucleotide signaling in cavernous smooth muscle $J$ Sex Med 2: 478-491. [Crossref]

47. Lin CS, Xin ZC, Wang Z, Lin G, Lue TF (2008) Molecular Yin and Yang of erectile function and dysfunction. Asian J Androl 10: 433-440. [Crossref]

48. Hurt KJ, Musicki B, Palese MA, Crone JK, Becker RE, et al. (2002) Akt-dependent phosphorylation of endothelial nitric-oxide synthase mediates penile erection. Proc Natl Acad Sci U S A 99: 4061-4066. [Crossref]

49. Bivalacqua TJ, Usta MF, Champion HC, Kadowitz PJ, Hellstrom WJ (2003) Endothelia dysfunction in erectile dysfunction: role of the endothelium in erectile physiology and disease. J Androl 24: S17-37. [Crossref]

50. A. L. Burnett (2004) Novel nitric oxide signaling mechanisms regulate the erectile response. Int J Impot Resvol 16: S15-S19. [Crossref]

51. G Corona G, Petrone L, Mannucci E, Mansani R, Balercia G, et al. (2005) Difficulties in achieving vs maintaining erection: organic, psychogenic and relational determinants. Int J Impot Res 17: 252-258. [Crossref]

52. Wessells H, Teal TH, Engel K, Sullivan CJ, Gallis B, et al. (2006) Fluid shear stres induced nitric oxide production in human cavernosal endothelialcells:inhibition by hyperglycaemia. BJU International 97: 1047-1052.[Crossref]

53. Michel T, Feron O (1997) Nitric oxide synthases: which, where, how, and why? J Clin Invest 100: 2146-2152. [Crossref]

54. Lin C, Lau A, Bakircioglu E (1998) Analysis of neuronal nitric oxide synthase is of or $m$ expression and identification of human nNOS. Biochem Biophy Res Comm 253 : 388-394. 
Mercado C (2016) Adipose-derived adult stem cells and new technique for intracavernosal injection for erectile dysfunction: novel approach to treat diabetes mellitus. Erectus Shot Technique

55. Ning H, Qiu X, Baine L, Lin G, Lue TF, et al. (2012) Effects of high glucose on human cavernous endothelial cells. Urology 80: 1162. [Crossref]

56. Lin CS (2009) Phosphodiesterase type 5 regulation in the penile corpora cavernosa. $J$ Sex Med 6 Suppl 3: 203-209. [Crossref]

57. Lin CS, Lin G, Xin ZC, Lue TF (2006) Expression, distribution and regulation of phosphodiesterase 5. Curr Pharm Des 12: 3439-3457. [Crossref]

58. Shamloul R, Ghanem H (2013) Erectile dysfunction. Lancet 381: 153-165. [Crossref]

59. Albersen M, Orabi H, Lue TF (2012) Evaluation and treatment of erectile dysfunction in the aging male: a mini-review. Gerontology 58: 3-14. [Crossref]

60. Montorsi F, Briganti A, Salonia A, et al. (2003) Erectile dysfunction prevalence, time of onset and association with risk factors in 300 consecutive patients with acute chest pain and angiographically documented coronary artery disease. Eur Urol 44: 360-364. [Crossref]

61. Akishita M1, Hashimoto M, Ohike Y, Ogawa S, Iijima K, et al. (2007) Low testosterone level is an independent determinant of endothelial dysfunction in men. Hypertens Res 30: 1029-1034. [Crossref]

62. Carvalheira AA, Pereira NM, Maroco J, Forjaz V (2012) Dropout in the treatment of erectile dysfunction with PDE5: a study on predictors and a qualitative analysis of reasons for discontinuation. J Sex Med 9: 2361-2369. [Crossref]

63. da Silva Meirelles L, Chagastelles PC, Nardi NB (2006) Mesenchymal stem cells reside in virtually all post-natal organs and tissues. J Cell Sci 119: 2204-2213. [Crossref]

64. Crisan M, Yap S, Casteilla L, Chen CW, Corselli M, et al. (2008) A perivascular origin for mesenchymal stem cells in multiple human organs. Cell Stem Cell 3: 301-313. [Crossref]

65. Lin G, Garcia M, Ning H, Banie L, Guo YL, et al. (2008) Defining stem and progenitor cells within adipose tissue. Stem Cells Dev 17: 1053-1063. [Crossref]

66. Braun J, Kurtz A, Barutcu N, Bodo J, Thiel A, et al. (2013) Concerted regulation of CD34 and CD105 accompanies mesenchymal stromal cell derivation from human adventitial stromal cell. Stem Cells Dev 22: 815-827 [Crossref]

67. Corselli M, Chen CW, Sun B, Yap S, Rubin JP, et al. (2012) The tunica adventitia of human arteries and veins as a source of mesenchymal stem cells. Stem Cells Dev 21: 1299-1308. [Crossref]

68. Lin G, Xin Z, Zhang H, Banie L, Wang G, et al. (2012) Identification of active and quiescent adipose vascular stromal cells. Cytotherapy 14: 240-246. [Crossref]

69. Maumus M, Peyrafitte JA, D’Angelo R, Fournier-Wirth C, Bouloumié A, et al. (2011) Native human adipose stromal cells: localization, morphology and phenotype. Int $J$ Obes (Lond) 35: 1141-1153. [Crossref]

70. Zimmerlin L, Donnenberg VS, Pfeifer ME, Meyer EM, Péault B, et al. (2010) Stroma vascular progenitors in adult human adipose tissue. Cytometry A 77: 22-30. [Crossref]

71. Lin CS, Lue TF (2013) Defining vascular stem cells. Stem Cells Dev 22: 1018-1026. [Crossref]

72. Dominici M, Le Blanc K, Mueller I, Slaper-Cortenbach I, Marini F, et al. (2006) Minimal criteria for defining multipotent mesenchymal stromal cells. The International Society for Cellular Therapy position statement. Cytotherapy 8: 315-317. [Crossref]

73. Lin CS, Lue TF (2012) Adipose-derived stem cells: therapy through paracrine actions, in Stem Cells and Cancer StemCells, M. A. Hayat, Ed., vol. 4, pp. 203-216, Springer, New York, NY, USA.

74. Lin CS1, Xin ZC, Dai J, Lue TF (2013) Commonly used mesenchymal stem cell markers and tracking labels: Limitations and challenges. Histol Histopathol 28: 11091116. [Crossref]

75. Lin CS, Ning H, Lin G, Lue TF (2012) Is CD34 truly a negative marker for mesenchymal stromal cells? Cytotherapy 14: 1159-1163. [Crossref]

76. Simmons PJ, Torok-Storb B (1991) Identification of stromal cell precursors in human bone marrow by a novel monoclonal antibody, STRO-1. Blood 78: 55-62. [Crossref]

77. Simmons PJ, Torok-Storb B (1991) CD34 expression by stromal precursors in normal human adult bone marrow. Blood 78: 2848-2853. [Crossref]

78. Kolf CM, Cho E, Tuan RS (2007) Mesenchymal stromal cells. Biology of adult mesenchymal stem cells: regulation of niche, self-renewal and differentiation. Arthritis Res Ther 9: 204. [Crossref]

79. Lin G, Liu G, Banie L, Wang G, Ning H, et al. (2011) Tissue distribution of mesenchymal stem cell marker Stro-1. Stem Cells Dev 20: 1747-1752. [Crossref]
80. Caplan AI, Correa D (2011) The MSC: an injury drugstore. Cell Stem Cell 9: 11-15. [Crossref]

81. Prockop DJ, Oh JY (2012) Medical therapies with adult stem/progenitor cells (MSCs): a backward journey from dramatic results in vivo to the cellular and molecular explanations. J Cell Biochem 113: 1460-1469. [Crossref]

82. Murphy MB, Moncivais K, Caplan AI (2013) Mesenchymal stem cells: environmentally responsive therapeutics for regenerative medicine. Exp Mol Med 45.

83. Song YS (2015) Genomics/Stem Cells in Urology. Use of nanoparticles to monitor human mesenchymal stem cells transplanted into penile cavernosum of rats with erectile dysfunction. Korean J Urol 56: 280-287.

84. National Diabetes Statistics, National Diabetes Information Clearinghouse, National Institute of Diabetes and Digestive and Kidney Diseases(NIDDK), National Institutes of Health,2011,

85. Danaei G, Finucane MM, Lu Y, Singh GM, Cowan MJ, et al. (2011) National, regional, and global trends in fasting plasma glucose and diabetes prevalence since 1980 systematic analysis of health examination surveys and epidemiological studies with 370 country-years and 2.7 million participants. The Lancet 378: 31-40. [Crossref]

86. IDF Diabetes Atlas, International Diabetes Federation.

87. Park K, Ryu KS, Li WJ, Kim SW, Paick JS (2008) Chronic treatment with a type 5 phosphodiesterase inhibitor suppresses apoptosis of corporal smooth muscle by potentiating Akt signaling in a rat model of diabetic erectile dysfunction. Eur Urol 53: 1282-1288. [Crossref]

88. Lewis RW, Fugl-Meyer KS, Corona G, Hayes RD, Laumann EO, et al. (2010) Definitions/epidemiology/risk factors for sexual dysfunction. J Sex Med 7: 1598-1607. [Crossref]

89. Feldman HA, Goldstein I, Hatzichristou DG, Krane RJ, McKinlay JB (1994) Impotence and its medical and psychosocial correlates: results of the Massachusetts Male Aging Study. J Urol 151: 54-61. [Crossref]

90. Ponholzer A, Temml C, Mock K, Marszalek M, Obermayr R, et al. (2005) Prevalence and risk factors for erectile dysfunction in 2869 men using a validated questionnaire. Eur Urol 47: 80-85. [Crossref]

91. Albersen M, Lin G, Fandel TM, Zhang H, Qiu X, et al. (2011) Functional, metabolic, and morphologic characteristics of a novel rat model of type 2 diabetes-associated erectile dysfunction. Urology 78: 476. [Crossref]

92. Dashwood MR, Crump A, Shi-Wen X, Loesch A (2011) Identification of neuronal nitric oxide synthase (nNOS) in human penis: a potential role of reduced neuronallyderived nitric oxide in erectile dysfunction. Curr Pharm Biotechnol 12: 1316-1321. [Crossref]

93. Zhou F, Xin H, Liu T, Li GY, Gao ZZ, et al. (2012) Effects of icariside II on improving erectile function in rats with streptozotocin-induced diabetes. J Androl 33: 832-844. [Crossref]

94. Cellek S, Foxwell NA, Moncada S (2003) Two phases of nitrergic neuropathy in streptozotocin-induced diabetic rats. Diabetes 52: 2353-2362. [Crossref]

95. Qiu X, Lin G, Xin Z, Ferretti L, Zhang H, et al. (2013) Effects of low-energy shockwave therapy on the erectile function and tissue of a diabetic rat model. J Sex Med 10: 738746. [Crossref]

96. Costa C, Soares R, Castela A, Adães S, Hastert V, et al. (2009) Increased endothelia apoptotic cell density in human diabetic erectile tissue - comparison with clinical data J Sex Med 6: 826-835. [Crossref]

97. Ning H, Lin G, Lue TF, Lin CS (2013) A coculture system of cavernous endothelial and smooth muscle cells. Int J Impot Res 25: 63-68. [Crossref]

98. Bochinski D, Lin GT, Nunes L, Carrion R, Rahman N, et al. (2004) The effect of neura embryonic stem cell therapy in a rat model of cavernosal nerve injury. BJU Int 94 : 904-909. [Crossref]

99. Y Kim Y, de Miguel F, Usiene I, Kwon D, Yoshimura N, et al. (2006) Injection of skeletal muscle-derived cells into the penis improves erectile function. Int J Impot Res 18: 329-334.[Crossref]

100. Fall PA, Izikki M, Tu L, Swieb S, Giuliano F, et al. (2009) Apoptosis and effects of intracavernous bone marrow cell injection in a rat model of postprostatectomy erectile dysfunction. Eur Urol 56: 716-725. [Crossref]

101. Albersen M, Fandel TM, Lin G, Wang G, Banie L, et al. (2010) Injections of adipose tissue-derived stem cells and stem cell lysate improve recovery of erectile function in a rat model of cavernous nerve injury. $J$ Sex Med 7: 3331-3340. [Crossref] 
Mercado C (2016) Adipose-derived adult stem cells and new technique for intracavernosal injection for erectile dysfunction: novel approach to treat diabetes mellitus. Erectus Shot Technique

102. KendirciM,TrostL,BakondiB, WhitneyMJ,Hellstrom WJ,etal.(2010)Transplantation of nonhematopoietic adult bone marrow stem/progenitorcellsisolatedbyp75nerve growth factor receptor into the penis rescues erectile function in a rat model of cavernous nerve injury. J Urol 184: 1560-1566. [Crossref]

103. Lin G, Albersen M, Harraz AM, Fandel TM, Garcia M, et al. (2011) Cavernous nerve repair with allogenic adipose matrix and autologous adipose-derived stem cells. Urology 77: 1509. [Crossref]

104. Woo JC, Bae WJ, Kim SJ, Kim SD, Sohn DW, et al. (2011) Transplantation of muscle-derived stem cells into the corpus cavernosum restores erectile function in a rat model of cavernous nerve injury. Korean J Urol 52: 359-363. [Crossref]

105. Fandel TM, Albersen M, Lin G, Qiu X, Ning H, et al. (2012) Recruitment of intracavernously injected adipose-derived stem cells to the major pelvic ganglion improves erectile function in a rat model of cavernous nerve injury. Eur Urol 61: 201-210. [Crossref]

106. Kim SJ, Choi SW, Hur KJ, Park SH, Sung YC, et al. (2012) Synergistic effect of mesenchymal stemcells infected with recombinant adenovirus expressing human BDNF non erectile function in a rat model of cavernous nerve injury. Korean J Urol 53:726-732. [Crossref]

107. Kovanecz I, Rivera S, Nolazco G, Vernet D, Segura D, et al. (2012) Separate or combined treatments with daily sildenafil,molsidomine,ormuscle derived stemcells prevent erectile dysfunction in a rat model of cavernosal nerve damage. J Sex Med 9: 2814-2826. [Crossref]

108. Piao S, Kim IG, Lee JY, Hong SH, Kim SW, et al. (2012) Therapeutic effect of adipose-derived stem cells and BDNF-immobilized PLGA membrane in a rat model of cavernous nerve injury. J Sex Med 9: 1968-1979. [Crossref]

109. Qiu X, Villalta J, Ferretti L, Fandel TM, Albersen M, et al. (2012) Effects of intravenous injection of adipose-derived stem cells in a rat model of radiation therapyinduced erectile dysfunction. J Sex Med 9: 1834-1841. [Crossref]

110. Qiu X, Fandel TM, Ferretti L, Albersen M, Orabi H, et al. (2012) Both immediate and delayed intracavernous injection of autologous adipose-derived stromal vascular fraction enhances recovery of erectile function in a rat model of cavernous nerve injury. Eur Urol 62: 720-727. [Crossref]

111. Jeong HH, Piao S, Ha JN, Kim IG, Oh SH, et al. (2013) Combined therapeutic effect of udenafil and adipose-derived stem cell (ADSC)/brain-derived neurotrophic factor (BDNF)-membrane system in a rat model of cavernous nerve injury. Urology 81: 1108. [Crossref]

112. Kim IG, Piao S, Lee JY, Hong SH, Hwang TK, et al. (2013) Effect of an adiposederived stem cell and nerve growth factor-incorporated hydrogel on recovery of erectile function in a rat model of cavernous nerve injury. Tissue Eng Part A 19: 14-23. [Crossref]

113. You D, Jang MJ, Lee J, Suh N, Jeong IG, et al. (2013) Periprostatic implantation of human bone marrow-derived mesenchymal stem cells potentiates recovery of erectile function by intracavernosal injection in a rat model of cavernous nerve injury. Urology 81: 104-110. [Crossref]

114. You D, Jang MJ, Lee J, Jeong IG, Kim HS, et al. (2013) Comparative analysis of periprostatic implantation and intracavernosal injection of human adipose tissuederived stem cells for erectile function recovery in a rat model of cavernous nerve injury. Prostate73: 278-286. [Crossref]

115. Choi WY, Jeon HG, Chung Y, Lim JJ, Shin DH, et al. (2013) Isolation and characterization of novel, highly proliferative human CD34/CD73-double-positive testis-derived stem cells for cell therapy. Stem Cells Dev 22: 2158-2173. [Crossref]

116. Ying C, Yang M, Zheng X, Hu W, Wang X (2013) Effects of intracavernous injection of adipose-derived stem cells on cavernous nerve regeneration in a rat model. Cell Mol Neurobiol 33: 233-240. [Crossref]
117. Bivalacqua TJ, Deng W, Kendirci M, Usta MF, Robinson C, et al. (2007) Mesenchymal stem cells alone or ex vivo gene Modified with endothelial nitric oxide synthase reverse age-associated erectile dysfunction. Am J Physiol Heart Circ Physiol 292: H1278-H1290. [Crossref]

118. Nolazco G, Kovanecz I, Vernet D, Gelfand RA, Tsao J, et al. (2008) Effect of musclederived stem cells on the restoration of corpora cavernosa smooth muscle and erectile function in the aged rat. BJU Int 101: 1156-1164. [Crossref]

119. Abdel Aziz MT1, El-Haggar S, Mostafa T, Atta H, Fouad H, et al. (2010) Effect of mesenchymal stem cell penile transplantation on erectile signaling of aged rats. Andrologia 42: 187-192. [Crossref]

120. Huang YC, Ning H, Shindel AW, Fandel TM, Lin G, et al. (2010) The effect of intracavernous injection of adipose tissue-derived stem cells on hyperlipidemiaassociated erectile dysfunction in a rat model. J Sex Med 7: 1391-1400. [Crossref]

121. Castiglione F, Hedlund P, Van der Aa F, Bivalacqua TJ, Rigatti P, et al. (2013) Intratunical injection of human adipose tissue-derived stem cells prevents fibrosis and is associated with improved erectile function in a rat model of Peyronie's disease. Eur Urol 63: 551-560. [Crossref]

122. Bahk JY, Jung JH, Han H, Min SK, Lee YS (2010) Treatment of diabetic impotence with umbilical cord blood stem cell intracavernosal transplant: preliminary report of 7 cases. Exp Clin Transplant 8: 150-160. [Crossref]

123. Garcia MM, Fandel TM, Lin G, Shindel AW, Banie L, et al. (2010) Treatment of erectile dysfunction in the obese type 2 diabetic ZDF rat with adipose tissue-derived stem cells. J Sex Med 7: 89-98. [Crossref]

124. Gou X, He WY, Xiao MZ, Qiu M, Wang M, et al. (2011) Transplantation of endothelial progenitor cells transfected with VEGF165 to restore erectile function in diabetic rats. Asian J Androl 13: 332-338. [Crossref]

125. Qiu X, Lin H, Wang Y, Yu W, Chen Y, et al. (2011) Intracavernous transplantation of bone marrow-derived mesenchymal stemcells restores erectile function of streptozocin-induced diabetic rats. J Sex Med 8: 427-436. [Crossref]

126. Qiu X, Sun C, Yu W, Lin H, Sun Z, et al. (2012) Combined strategy of mesenchyma stem cell injection with vascular endothelial growth factor gene therapy for the treatment of diabetes-associated erectile dysfunction. J Androl 33: 37-44. [Crossref]

127. Sun C, Lin H, Yu W, Li X, Chen Y, et al. (2012) Neurotrophic effect of bone marrow mesenchymal stem cells for erectile dysfunction in diabetic rats. Int $J$ Androl 35: 601-607. [Crossref]

128. Nishimatsu H1, Suzuki E, Kumano S, Nomiya A, Liu M, et al. (2012) Adrenomedullin mediates adipose tissue-derived stem cell-induced restoration of erectile function in diabetic rats. J Sex Med 9: 482-493. [Crossref]

129. Ryu JK, Tumurbaatar M, Jin HR, Kim WJ, Kwon MH, et al. (2012) Intracavernous delivery of freshly isolated stromal vascular fraction rescues erectile function by enhancing endothelial regeneration in the streptozotocin-induced diabetic mouse. $J$ Sex Med 9: 3051-3065. [Crossref]

130. He Y, He W, Qin G, Luo J, Xiao M (2014) Transplantation KCNMA1 modified bone marrow-mesenchymal stem cell therapy for diabetes mellitus-induced erectile dysfunction. Andrologia 46: 479-486. [Crossref]

131. Liu G, Sun X, Bian J, Wu R, Guan X, et al. (2013) Correction of diabetic erectile dysfunction with adipose derived stem cells modified with the vascular endothelial growth factor gene in a rodent diabetic model. PLoS One 8: e72790. [Crossref]

132. JMeyer J, Salamon A, Herzmann N, Adam S, Kleine HD, et al. (2015) Isolation and Differentiation Potential of Human Mesenchymal Stem Cells From Adipose Tissue Harvested by Water Jet-Assisted Liposuction. Aes Surg J 1-10. [Crossref]

Copyright: (C2016 Mercado C. This is an open-access article distributed under the terms of the Creative Commons Attribution License, which permits unrestricted use, distribution, and reproduction in any medium, provided the original author and source are credited. 